\title{
ARCHEOLOGICKÝ VÝSKUM NA ZANIKNUTOM HRADE ŠIRKOVCE-KAPLA (OKRES RIMAVSKÁ SOBOTA)
}

\author{
ALEXANDER BOTOŠ
}

\begin{abstract}
Abstrakt: V predkladanom príspevku hodnotime výsledky prvého archeologického výskumu na zaniknutom hrade Širkovce-Kapla. Archeologický výskum bol vykonaný sondážnou metódou, odkrytých bolo celkom 7 sond (sondy S 1-7/2013). Sondami S 1-5/2013 boli odkryté základy hradnej cisterny (s rozmermi $2,02 \times 3,45 \mathrm{~m})$, zhotovenej z pálených tehál. Cisterna pochádza z obdobia 15 . storočia. V sondách S 6-7/2013 boli odkryté základy jednopriestorového objektu, pravdepodobne hospodárskej funkcie, s rozmermi 1,94 × 3,3 m, datovaného do obdobia konca 15. až 16. storočia. Predpokladané najstaršie osidlenie hradu z 13. storočia nebolo preukázané.
\end{abstract}

Kl'účové slová: hrad Širkovce-Kapla - hradná cisterna-komorové kachlice.

\section{Archaeological Research into the Defunct Širkovce-Kapla Castle (Rimavská Sobota District)}

Abstract: This contribution assesses the results of the first archaeological research into the defunct castle Sirkovce-Kapla. The research was conducted by means of probing, with seven probes (S 1-7/2013). Probes S 1-5/2013 uncovered the foundations of the castle cistern $(2.02 \times 3.45 \mathrm{~m})$ made of fired bricks. The cistern comes from the 15th century. Probes S 6-7/2013 unearthed the foundations of a single-space feature $(1.94 \times 3.3 \mathrm{~m})$, probably of economic function and dated to the late 15 th -16 th century. The presumed earliest settlement of the castle in the 13th century was not confirmed.

Key words: Širkovce-Kapla castle - castle cistern - chamber tiles.

Zaniknutý hrad Kapla je situovaný na dominantnom návrší, v juhozápadnej časti extravilánu obce Širkovce, ktoré sú od Rimavskej Soboty vzdialené 15 km južným smerom (obr. 1).

Na hrade Kapla nebol doposial' vykonaný žiadny archeologický výskum, vykonané boli len povrchové zbery a prospekcie.

Na juhovýchodnej strane hradného kopca boli povrchovým zberom zistené nálezy eneolitickej badenskej kultúry. Môžeme teda uvažovat' o výšinnej osade badenskej kultúry, skupiny Ózd.

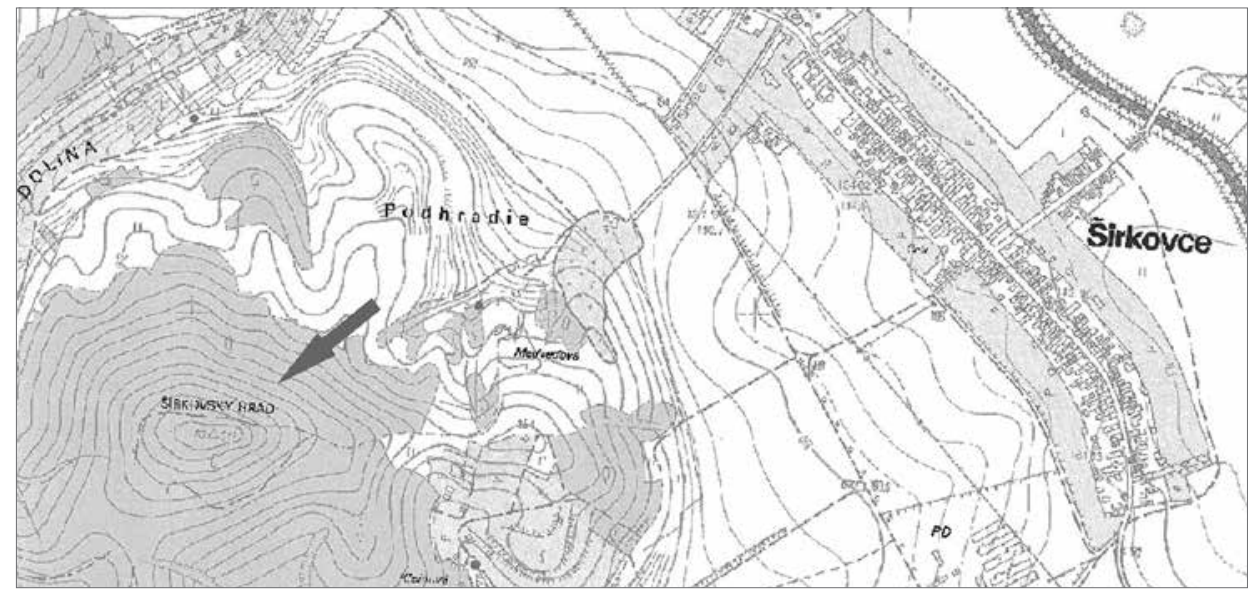

Obr. 1. Hrad Širkovce-Kapla. Výsek z mapy Základná mapa SR, klad listov 47-01-07, 1984, mierka 1:10 000.

Abb. 1. Burg Širkovce-Kapla. Ausschnitt aus der Grundkarte der Slowakischen Republik, Blattschnitt 47-01-07, 1984, Maßstab $1: 10000$. 
Ďalšie praveké nálezy zo skúmanej lokality predstavujú keramické fragmenty neskorobronzovej kyjatickej kultúry. Z hradného kopca pochádzajú aj zberové nálezy z doby laténskej, ako aj z mladšej doby rímskej.

Údaje o vzniku hradu Kapla nie sú jednoznačné. Hrad mal byt' postavený v roku 1264 (Kol. 1978, 131). Vznik hradu v období 13. storočia indikujú aj keramické fragmenty zistené povrchovým zberom (Plaček-Bóna 2007, 295). Mad’arský historik E. Fügedi datuje výstavbu hradu Kapla do rokov 1312-1326 (Plaček-Bóna 2007, 295).

Hrad bol pôvodne rodovým sídlom Ratoldovcov, v 14. storočí ho získali Lorántfyovci. Na konci 14. storočia hrad získava do držby panovník Žigmund Luxemburský.

Informácie o zániku hradu sa rôznia. V roku 1447 je o hrade zachovaná písomná zmienka, v ktorej sa uvádza „vrch Kapla, na ktorom stál hrad Serke“ (Plaček-Bóna 2007, 295). V tomto období hrad získali bratrícke oddiely, ktoré v roku 1443 prepadol Ján Jiskra. Posledné oddiely bratríkov z hradu však vyhnal až král' Matej Korvín v roku 1460 (Plaček-Bóna 2007, 295).

Podl'a iných údajov hrad zanikol až počas tureckých vojen v 16. storočí (Kol. 1978, 131) alebo až v 17. storočí (Kol. 1969, 247).

V súčasnosti nie je jednoznačná presná objektová skladba hradu, nakol'ko na hrade nie sú zachované žiadne nadzemné konštrukcie. Zaniknutý hrad dosahoval spolu s valmi dížku viac ako $180 \mathrm{~m}$. Rozloha hradného jadra je pomerne malá, jadro je obdížnikovité s rozmermi ca $55 \times 20 \mathrm{~m}$. Hrad bol v západnej časti opatrený priečnou stavbou, na ktorú zvonka priliehal parkán. Na parkán nadväzovala znížená čast' horného hradu s blokovou zástavbou. Okolo celého hradu dôsledne oblieha val, ktorý vymedzoval okružnú priekopu, na dvoch stranách zdvojenú. Vo východnej časti hradu sa predpokladala existencia veže alebo hradného paláca (Plaček-Bóna 2007, 295-296).

Najvyššie položená úroveň hradného jadra je jeho východná až severovýchodná čast'. Najnižšie je položená západná čast' hradného jadra. Celý areál hradu je krytý lesným porastom.

Počas archeologického výskumu v sezóne 2013 bolo odkrytých celkom sedem sond, označených ako S 1-7/2013. Sondy boli situované v mieste dvoch výrazných terénnych depresií vo východnej časti hradného jadra za účelom overenia ich pôvodných funkcií (obr. 2-3). Sondy boli vedené ako rezy a bola nimi preskúmaná plocha $42,4 \mathrm{~m}^{2}$ (ca $4 \%$ z celkovej predpokladanej plochy hradného jadra).

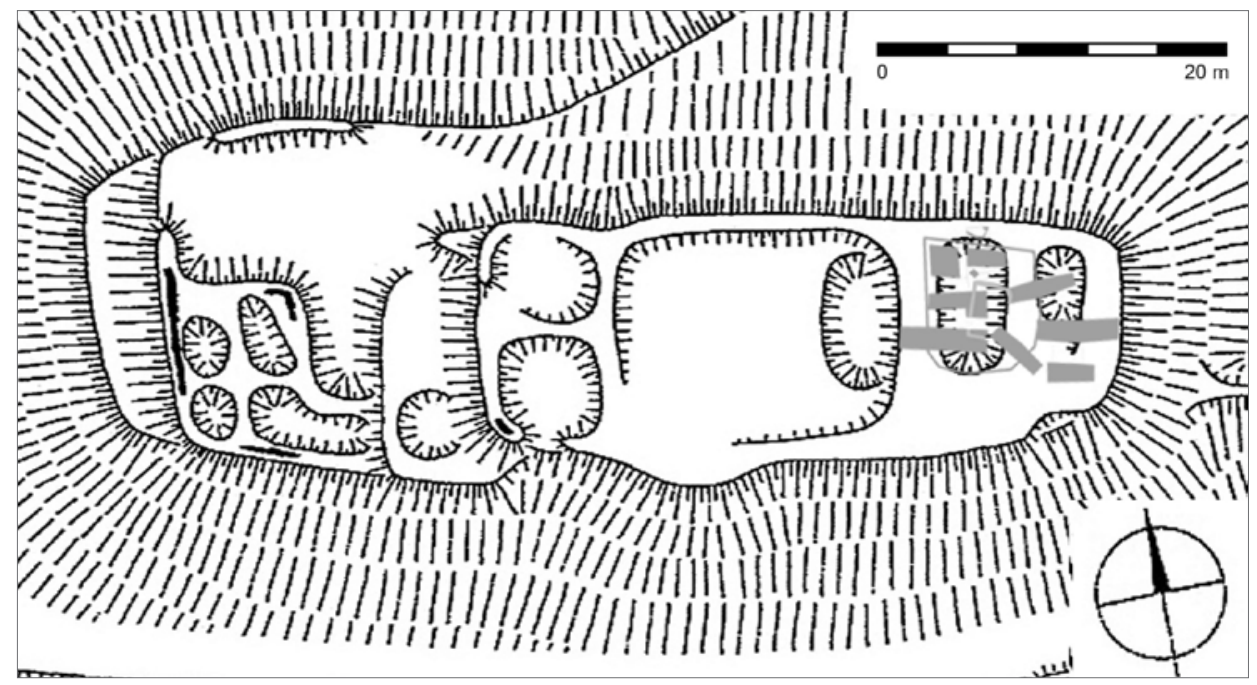

Obr. 2. Hrad Širkovce-Kapla. Sondy S 1-7/2013 na podklade terénneho náčrtu reliéfneho utvárania hradu podl’a Plaček-Bóna 2007. Vyhotovil D. Bešina.

Abb. 2. Burg Širkovce-Kapla. Sondierschnitte S 1-7/2013 Reliefform der Burg, Skizzenvorlage entnommen aus Plaček-Bóna 2007. Erstellt von D. Bešina. 


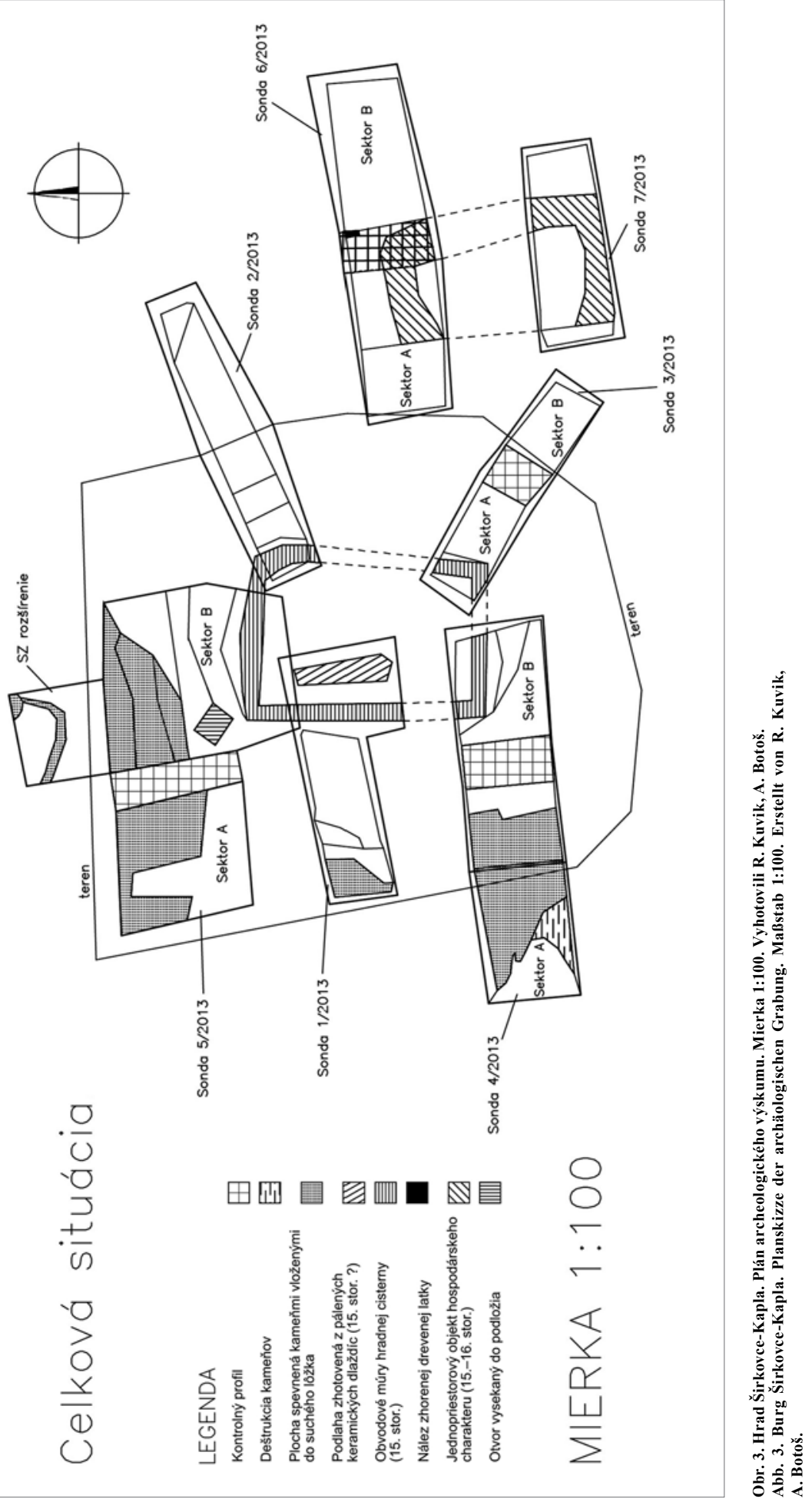


Sonda S 1/2013 bola situovaná v západnej časti výraznej terénnej depresie, orientovaná bola v smere západ-východ. V híbke $1,03 \mathrm{~m}$ od pôvodnej úrovne terénu bol zachytený múr, zhotovený z pálených tehál (prstoviek) s prímesou piesku. Rozmery tehál boli $18 \times 13 \times 5 \mathrm{~cm}$. Tehly boli spájané hrubozrnnou vápennou maltou, múr bol omietaný vápennou omietkou jemnozrnného charakteru. Šírka múru bola $0,38 \mathrm{~m}$, múr bol vedený v smere sever-juh.

V západnej časti sondy v híbke $0,28-0,32 \mathrm{~m}$ od pôvodnej úrovne terénu boli zistené ploché kamene, ukladané do suchého lôžka na ploche s rozmermi $80 \times 50 \mathrm{~cm}$. Najväčší kameň mal rozmery $16 \times 20 \times 4 \mathrm{~cm}$. Kamene boli ukončené zasekaným podložím.

$\mathrm{Z}$ dôvodu overenia založenia odkrytého múru sme východnú čast' sondy rozšírili južným smerom na ploche $1,40 \times 0,70 \mathrm{~m}$. V úrovni $3,98 \mathrm{~m}$ od pôvodnej úrovne terénu bola zachytená podlaha, zhotovená z pálených keramických dlaždíc s rozmermi $24 \times 22,5 \times 3,5 \mathrm{~cm}$ (obr. 4).

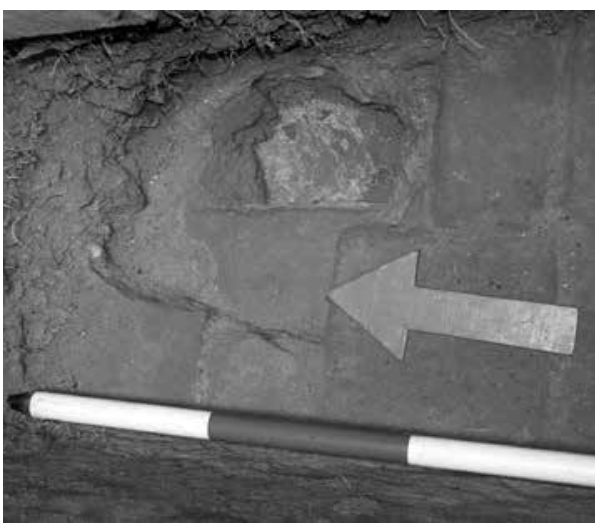

Obr. 4. Hrad Širkovce-Kapla. Podlaha zhotovená z pálených dlaždíc, odkrytá v hradnej cisterne, 15. storočie. Foto A. Botoš. Abb. 4. Burg Širkovce-Kapla. In der Burgzisterne freigelegter Fußboden aus gebrannten Fliesen, 15. Jhdt. Foto A. Botoš.

V mieste vylámania podlahy bola úroveň d’alej prehlbovaná, pod úrovňou podlahy bola odkrytá vrstva hrubozrnnej malty s mocnostou $2 \mathrm{~cm}$. Pod úrovňou malty bola zistená pálená tehla s výškou $7 \mathrm{~cm}$, ktorá bola uložená do hrubozrnnej malty. Odkrytú terénnu situáciu interpretujeme ako nález staršej podlahy, zhotovenej z pálených tehál.

Výška múru zhotoveného z pálených tehál od zachovanej koruny až po úroveň dlažby bola 2,93-2,96m. Na niektorých miestach múru bola zistená vrstva jemnozrnnej vápennej omietky s mocnost'ou max. $2 \mathrm{~cm}$.

V sonde S 1/2013 boli zistené predovšetkým keramické nálezy vo fragmentárnom stave. Jeden $\mathrm{z}$ najucelenejších objavených nálezov je torzo džbánu s gul’ovitým telom a valcovitým hrdlom, zdobeným obežnými červenohnedými malovanými pásmi, do ktorých sú vyškrabávané obežné ryhy (tab. I:1). Džbán príbuznej profilácie pochádza z hradu Budín, z hradného paláca, kde je chronologicky zaradený do 15. storočia (Holl 1963, 349, obr. 30-31). Predmetné torzo džbánu zarad'ujeme rovnako do obdobia 15 . storočia.

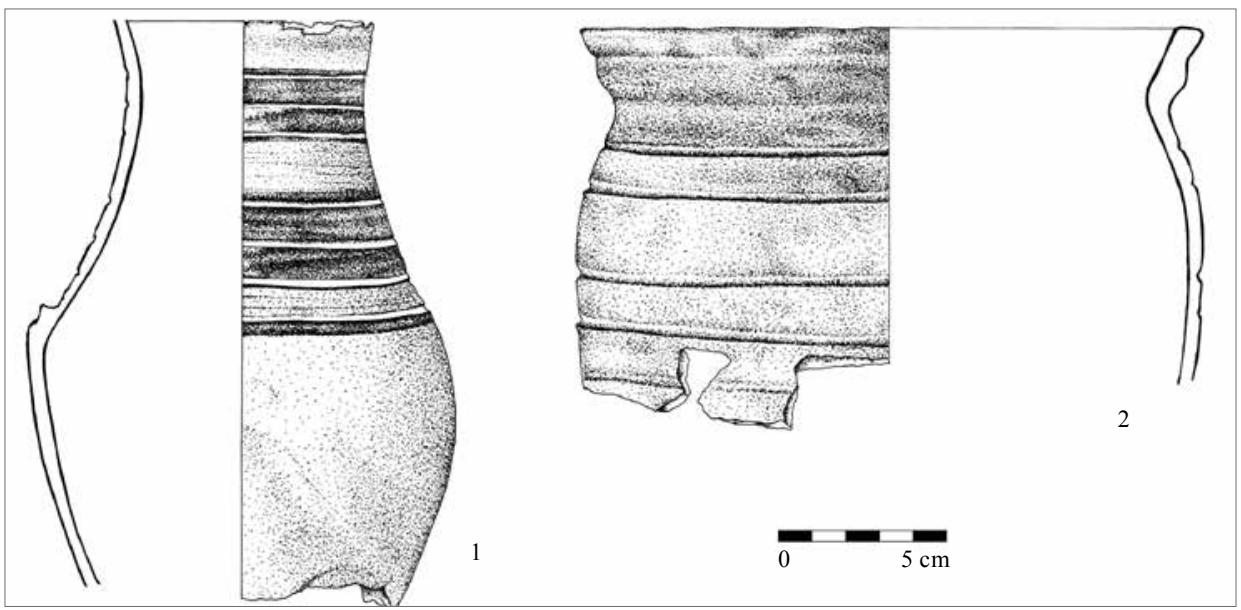

Tab. I. Hrad Širkovce-Kapla. Keramické fragmenty. 1 - sonda S 1/2013, 15. storočie; 2 - sonda S 5/2013, 13. storočie. Kresba D. Bešina. Taf. I. Burg Širkovce-Kapla. Keramikfragmente. 1 - Sondierschnitt S 1/2013, 15. Jhdt.; 2 - Sondierschnitt S 5/2013, 13. Jhdt. Zeichnung D. Bešina. 


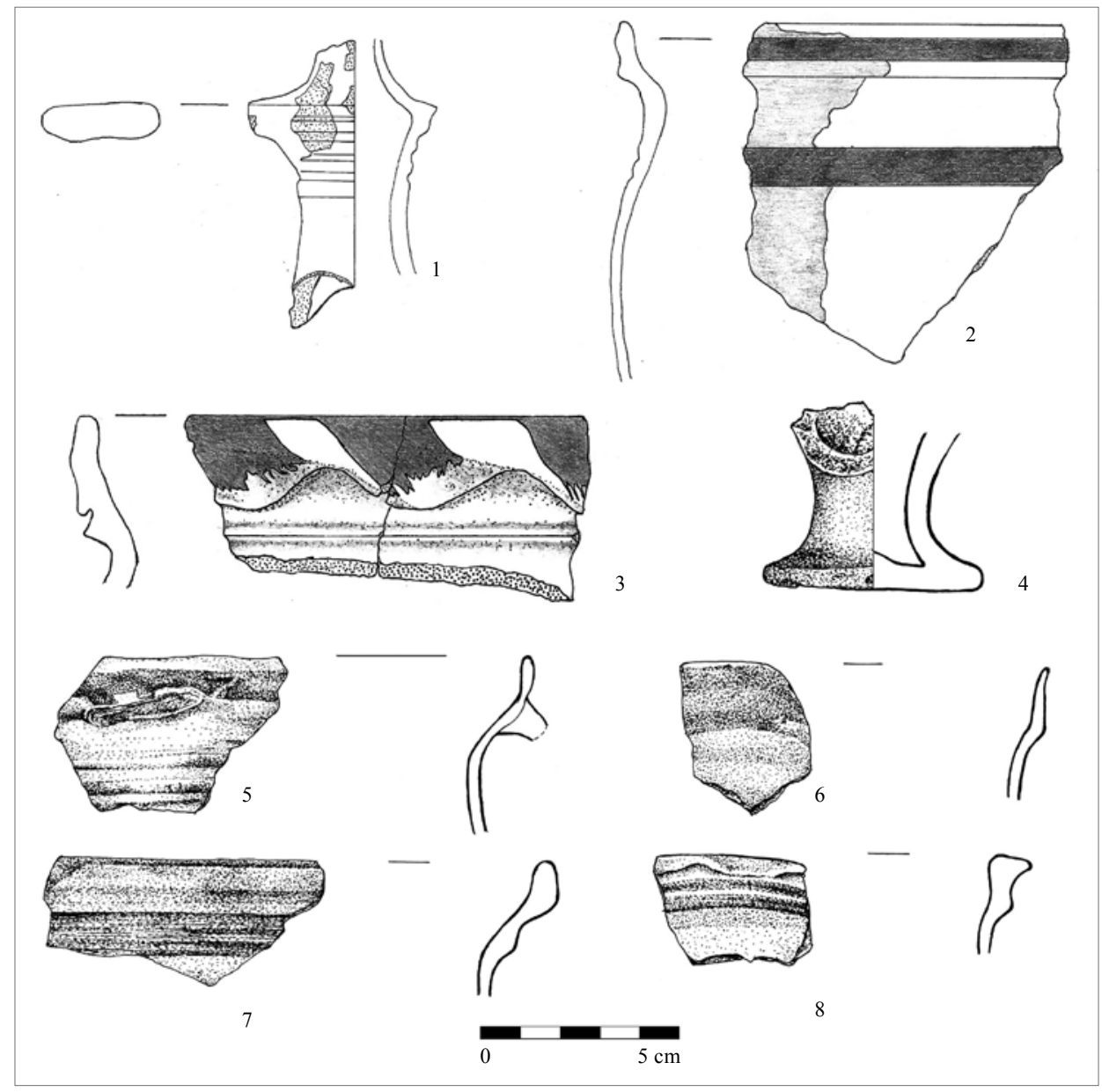

Tab. II. Hrad Širkovce-Kapla. Keramické fragmenty. 1-2 - sonda S 2/2013; 3-5 - sonda S 3/2013; 6-7 - sonda S 4/2014; 8 - sonda S 5/2013. Kresba D. Bešina, L. Podhorčík.

Taf. II. Burg Širkovce-Kapla. Keramikfragmente. 1-2 - Sondierschnitt S 2/2013; 3-5 - Sondierschnitt S 3/2013; 6-7 - Sondierschnitt S 4/2014; 8 - Sondierschnitt S 5/2013. Zeichnung D. Bešina, L. Podhorčík.

Sonda S 2/2013 bola situovaná v severovýchodnej časti terénnej depresie, orientovaná bola v smere severovýchod-juhozápad. V híbke $1,20 \mathrm{~m}$ od pôvodnej úrovne terénu bola zistená koruna múru, zhotovená $\mathrm{z}$ pálených tehál s rozmermi $19,8 \times 13 \times 3,2 \mathrm{~cm}$, spájaných vápennou maltou hrubozrnného charakteru. Orientácia múru bola v smere sever-juh. Múr bol zapustený do pieskovcového podložia, do úrovne $0,75-0,80 \mathrm{~m}$. Tehly boli tvrdého výpalu s obsahom hrubozrnných kremenných prímesí. Väčšina tehál bola opatrená odtlačkami prstov, tzv. prstovaním. Šírka odkrytého múru bola $0,38 \mathrm{~m}$, dížka odkrytého múru bola $1 \mathrm{~m}$.

V tejto sonde boli zistené predovšetkým keramické nálezy vo fragmentárnom stave. V sonde bol zistený aj nález torza ústia krčaha valcovitej profilácie (tab. II:1). Takmer identické nálezy krčahov boli odkryté aj na hrade Jáger (Lázár 1986, 51, obr. 4:4-5). Autorka štúdie takéto typy krčahov chronologicky zaradila do druhej polovice 16. storočia až začiatku 17. storočia (Lázár 1986, 51-52).

Počas výskumu bol zistený aj fragment $\mathrm{z}$ hrncovitej nádoby s dohora vytiahnutým a lievikovite von roztvoreným ústím, hrana okraja je oblá a je zosilnená plastickou lištou. Fragment je pod ústím opatrený obežným mal’ovaným pásom červenohnedej farby (tab. II:2). Hrniec 
s takmer identickou profiláciou tela a okraja ako hodnotený nález pochádza z lokality Rimavská Sobota-Sobôtka (Hoššo 1985, 236, obr. 3:6). Autor príspevku toto torzo hrnca chronologicky zaradil do 16. storočia (Hoššo 1985, 257). Hrniec s vel'mi blízkou profiláciou okraja bol odkrytý aj na hrade Jáger (Lázár 1986, 48, obr. 1:1), autorka príspevku ho chronologicky zaradila do druhej polovice 16. storočia až začiatku 17. storočia (Lázár 1986, 48).

Zo sondy S 2/2013 bol získaný aj nález železnej drumble (tab. III:1). Drumbla patrí k typu s vel'kou ústnou čast’ou, hrací tŕn sa kompletne nezachoval. Ako analogický nález môžeme uviest' nález drumble z Košíc - Kováčskej ulice, ktorá je datovaná do polovice 15. storočia (Rusnák 2009, 405, obr. 9:8). Drumbl'u zo sondy môžeme na základe sprievodného keramického materiálu zaradit' do obdobia 16. storočia až 17. storočia.

Sonda S 3/2013 bola situovaná v juhovýchodnej časti terénnej depresie, orientovaná bola v smere severozápad-juhovýchod. V híbke $0,90-1,20 \mathrm{~m}$ od pôvodnej úrovne terénu bolo zachytené juhovýchodné nárožie odkrývaného objektu. Šírka múru bola $30-31 \mathrm{~cm}$. Koruna múru bola zhotovená z pálených tehál, spájaných vápennou maltou hrubozrnného charakteru. Orientácia odkrytého juhovýchodného nárožia objektu bola sever-juh.

Zo sondy bol získaný pomerne bohatý keramický materiál, pozornost' si zasluhuje nález z hrncovitej nádoby (tab. II:3). Fragment je profilovaný výraznou obežnou plastickou lištou, je zdobený plastickým pretláčaním, ako aj červenohnedým mal'ovaním vo forme krátkych šikmých pásov.

Džbán s takmer identickou profiláciou okraja, ako aj s identickou výzdobnou technológiou (plastické pretláčanie) ako hodnotený nález pochádza z mesta Plzeň (Nekuda-Reichertová 1968, 222 , obr. 90:2) a je datovaný do 15 . storočia $(1968,215)$. Podobne chronologicky zarad'ujeme aj vyššie opísaný fragment.

V úrovni $0,50-0,80 \mathrm{~m}$ od pôvodnej úrovne terénu bol zistený fragment $\mathrm{z}$ gotického pohára (tab. II:4), zachovaná je len čast' dna s nôžkou. Takéto typy pohárov sú oblúbené v materiálnej náplni bielej stredovekej keramiky, ktorá je pre územie juhu stredného Slovenska dominantná a charakteristická. Obdobne profilované gotické poháre sú pomerne bežné v období 15. storočia (Hoššo 1985, 250).

V sonde bol objavený aj fragment z džbána s lievikovite von vyhnutým a jemne dohora vytiahnutým ústím. Džbán bol opatrený pásikovým uškom, je zdobený obežným červenohnedým mal'ovaným pásom (tab. II:5). Ako analogický nález $\mathrm{k}$ vyššie opísanému fragmentu môžeme uviest' nález džbána s okrajom takmer identickej profilácie, pochádzajúci z Budína, z hradného paláca, ktorý je chronologicky zaradený do 15. storočia (Holl 1963, 379, obr. 77:13).

V sonde $\mathrm{S} 2 / 2013$, v úrovni 0,0-0,60 m od pôvodnej úrovne terénu, bol zistený aj nález torza komorovej kachlice. Čelná vyhrievacia stena je zdobená geometrickým motívom a je opatrená monochrómnou glazúrou zelenej farby. Torzo kachlice môžeme chronologicky zaradit’ do obdobia renesancie.

Reprezentantom železných predmetov získaných v predmetnej sonde, $\mathrm{v}$ úrovni $0,0-0,60 \mathrm{~m}$ od pôvodnej úrovne terénu, je nález masívneho železného hrotu (strelky) (tab. III:2) romboidnej profilácie. Nález môžeme na základe sprievodného keramického materiálu chronologicky zaradit' do obdobia 15.-16. storočia.

Väčšinu zistených keramických nálezov z výplne sondy S 3/2013 môžeme chronologicky zaradit' do obdobia záveru neskorého stredoveku až začiatku včasného novoveku (15.-16. storočie).

Sonda S 4/2013 bola situovaná v juhozápadnej časti terénnej depresie, orientovaná bola v smere západ-východ. V priestore sondy S 4/2013, v úrovni $0,24-0,30 \mathrm{~m}$ od pôvodnej úrovne terénu, boli zistené ploché kamene s max. rozmermi $17 \times 18 \times 5 \mathrm{~cm}$, uložené do suchého lôžka (hlinito-ílovitá jemnozrnná zemina čiernej farby). Kamene boli odkryté na ploche sondy $2,77 \times 1,55 \mathrm{~m}$ a orientované boli v smere sever-juh, pričom vytvárali „nárožie“ a stáčali sa na severozápad-sever (obr. 5).

$\mathrm{V}$ úrovni $0,82-1,19 \mathrm{~m}$ od pôvodnej úrovne terénu bola zachytená koruna juhozápadného nárožia tehlového objektu. Múr bol zhotovený z pálených tehál, spájaných vápennou maltou 


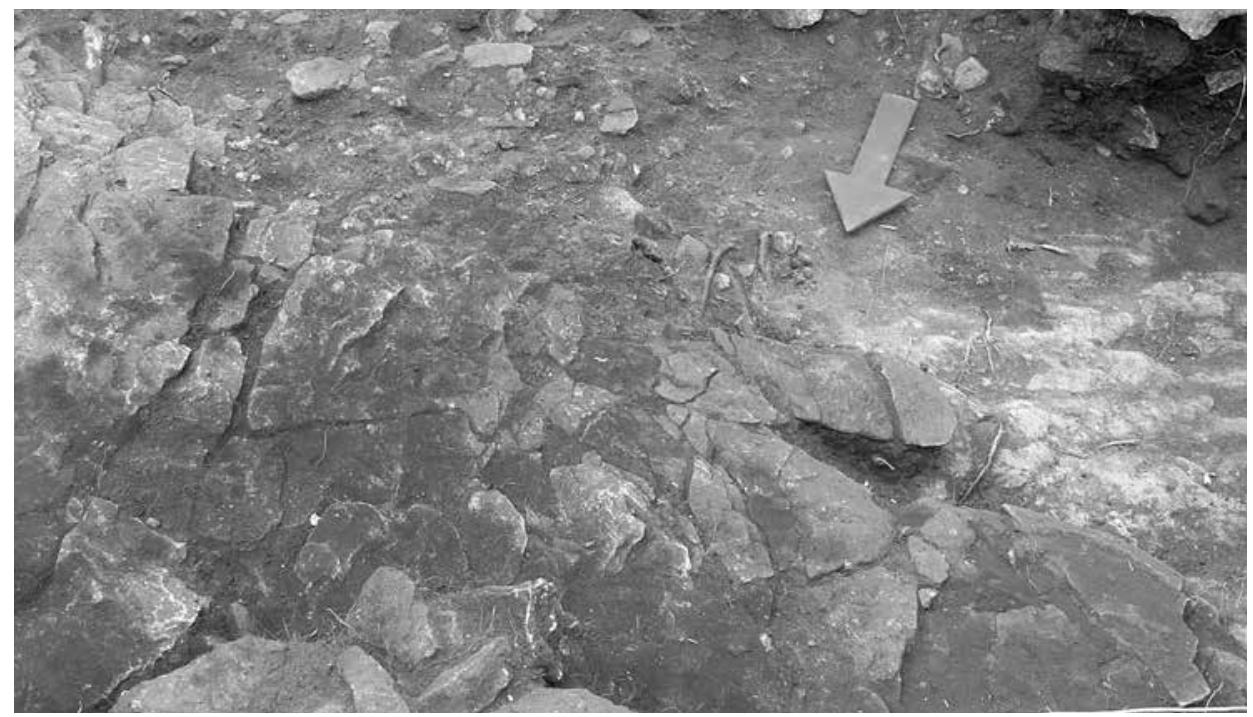

Obr. 5. Hrad Širkovce-Kapla. Ploché kamene uložené do suchého lôžka, sonda S 4/2013. Foto A. Botoš.

Abb. 5. Burg Širkovce-Kapla. Im Trockenbett ausgelegte Steine, Sondierschnitt S 4/2013. Foto A. Botoš.

hrubozrnného charakteru. Š́rka múru bola $0,33-0,38 \mathrm{~m}$. Dížka múru orientovaného v smere sever-juh bola $0,50 \mathrm{~m}$, dížka múru orientovaného v smere západ-východ bola $1,40 \mathrm{~m}$.

V sonde $\mathrm{S} 4 / 2013$ boli zistené predovšetkým keramické nálezy. Za nález s pomerne dobrou chronologickou funkciou môžeme označit' okrajový fragment z ústia džbána (tab. II:6). Ústie fragmentu je vysoko dohora vytiahnuté, fragment je zdobený mal’ovaným obežným pásom hnedočiernej farby. Ako analógie k tomuto nálezu môžeme uviest' nálezy džbánov z mesta Fil'akovo, z objektu studne (Hoššo 1985, 241, obr. 8:2, 5, 6), ktoré J. Hoššo zaradil do obdobia štrnásteho, ale predovšetkým 15. storočia (Hoššo 1985, 250).

Ďalším zisteným nálezom v predmetnej sonde je keramický fragment $\mathrm{z}$ hrncovitej nádoby (tab. II:7). Ústie je lievikovite von roztvorené a dohora vytiahnuté. Fragment je zdobený obežnými mal’ovanými pásmi červenohnedej farby. Ako analogický nález k tomuto nálezu môžeme uviest' nález torza hrnca z Rimavskej Soboty s takmer identickou profiláciou okraja (Hoššo 1985, 236, obr. 3:6). Predmetný nález je zaradený do obdobia 16. storočia (Hoššo 1985, 250-251).

Väčšinu zistených keramických nálezov zo sondy S 4/2013 môžeme chronologicky zaradit' do obdobia 15 . až 16 . storočia.

Sonda S 5/2013 bola situovaná v severozápadnej časti terénnej depresie, orientovaná bola v smere západ-východ.

V híbke 1,20 m od pôvodnej úrovne terénu bola zachytená koruna severného obvodového múru tehlového objektu. Koruna múru bola čiastočne sekundárne vylámaná. Severný obvodový múr bol zasekaný do pieskovcového podložia, do híbky $0,34 \mathrm{~m}$. Š́rka múru západného obvodového múru bola $0,34 \mathrm{~m}$, šírka severného obvodového múru bola $0,39 \mathrm{~m}$ (obr. 6).

V sondách S 1-5/2013 boli odkryté základy torzálnej architektúry zhotovenej z pálených tehál (prstoviek). Objekt bol obdížnikovitého pôdorysu s rozmermi 2,02×3,45 m, orientovaný bol v smere sever-juh. Odkrytý objekt bol zapustený do pieskovcového podložia, do úrovne 0,40-1,0 m v závislosti od konfigurácie terénu (obr. 7). V interiéri objektu bola v úrovni 3,98 m od pôvodnej úrovne terénu zistená podlaha, zhotovená z pálených dlaždíc. Výška múru zhotoveného z pálených tehál od zachovanej koruny až po úroveň podlahy bola $2,93-2,96 \mathrm{~m}$. Steny objektu boli omietnuté jemnozrnnou vápennou omietkou s mocnostou max. $2 \mathrm{~cm}$. Obvodové múry objektu sú subtílne (dva rady tehál so šírkou $0,38-0,40 \mathrm{~m}$ ). 


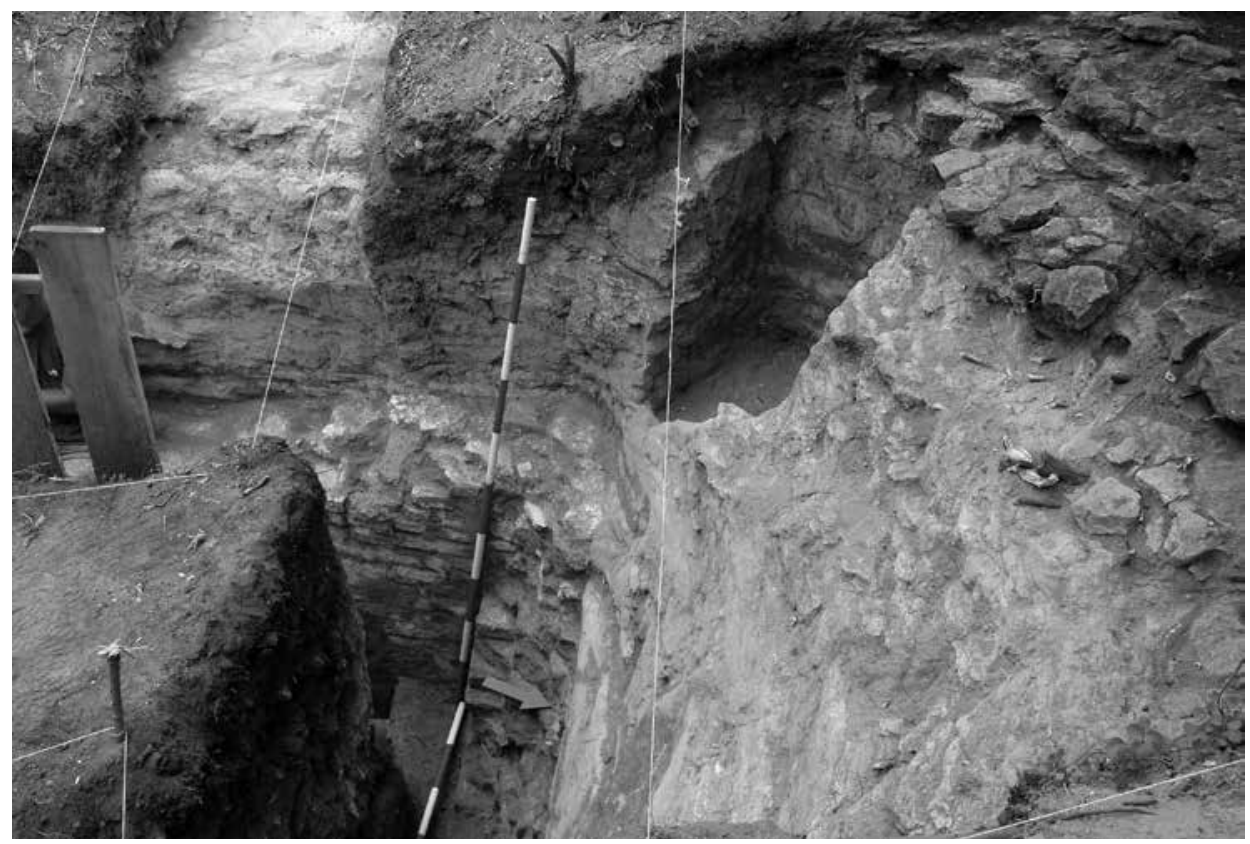

Obr. 6. Hrad Širkovce-Kapla. Severozápadné nárožie cisterny spolu s kamenným obkladom a terasovite zasekaným pieskovcovým podložím, sonda $S$ 5/2013. Foto A. Botoš.

Abb. 6. Burg Širkovce-Kapla. Nordwestecke der Zisterne mit Steinverkleidung und terrassenförmig zugehauenem Sandsteinuntergrund, Sondierschnitt S 5/2013. Foto A. Botoš.

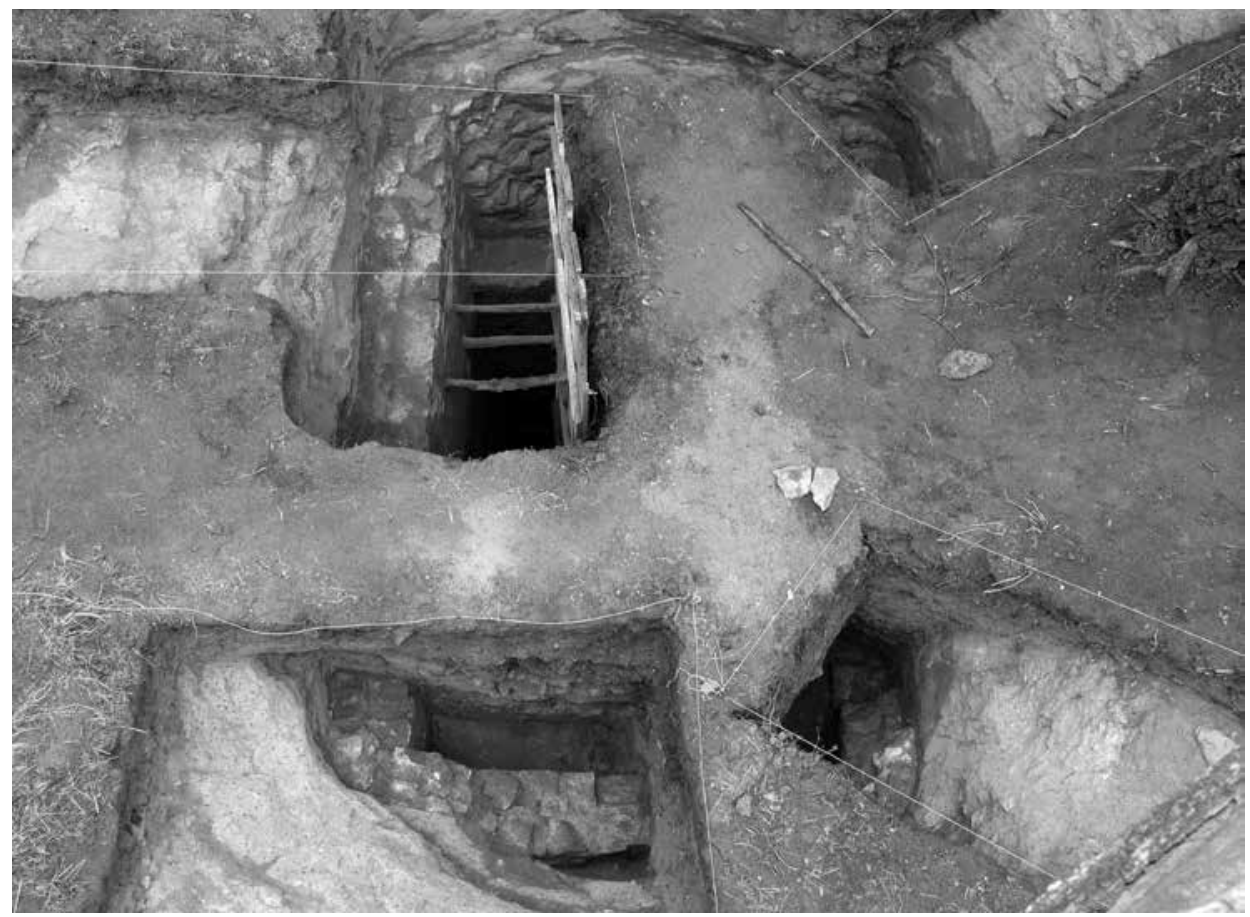

Obr. 7. Hrad Širkovce-Kapla. Pôdorys hradnej cisterny s vyspádovaným podložím, 15. storočie. Foto A. Botoš.

Abb. 7. Burg Širkovce-Kapla. Grundriss der Burgzisterne mit abschüssigem Untergrund, 15. Jhdt. Foto A. Botoš. 
Interpretácia tohto objektu nie je jednoznačná. Odkrytý objekt môžeme s najväčšou pravdepodobnost'ou interpretovat' ako nález hradnej cisterny. Táto interpretácia je však diskutabilná. Počas archeologického výskumu nebol zistený dvojitý obvodový plášt', komora cisterny, dokonca ani steny a dno cisterny neboli utesnené hydrofóbnym ílom, tak ako je štandardné u hradných cisterien (Poliak 2012, 59-61).

Ako jediné izolačné prvky $\mathrm{v}$ interiéri predpokladanej cisterny boli zistené: omietnutie tehlového obkladu cisterny jemnozrnnou vápennou (hydrofóbnou?) omietkou s mocnostou max. $2 \mathrm{~cm}$ a dve úrovne podláh zhotovených z pálených dlaždíc a tehál. Je otázne, do akej miery tieto opatrenia zabraňovali presakovaniu vody do pieskovcového podložia. K záveru, že odkrytý objekt slúžil s najväčšou pravdepodobnostou ako cisterna, sme dospeli aj na základe úpravy terénu v blízkom okolí odkrytého objektu. Bezprostredné okolie cisterny bolo vyspádované a vydláždené kameňom.

V západnej časti sondy S 5/2013, v úrovni $0,30-0,35 \mathrm{~m}$ od pôvodnej úrovne terénu, boli zistené ploché kamene uložené do suchého lôžka. Kamene boli zistené na ploche $1,32 \times 0,90 \mathrm{~m}$, orientované boli v smere západ-východ. Rovnako aj vo východnej časti sondy, v híbke $0,50-$ $0,55 \mathrm{~m}$ od pôvodnej úrovne terénu, boli zistené ploché kamene uložené do suchého lôžka. Kamene boli zistené na ploche $1,36 \times 0,70 \mathrm{~m}$, orientované boli v smere západ-východ. Kamenný „obklad“ bol vyspádovaný smerom k cisterne, navyše pôvodné pieskovcové podložie bolo aj terasovite upravované (zasekané) (obr. 6).

Obdobná situácia bola preukázaná aj v sondách S 1/2013, S 4/2013 a S 5/2013. Spevnená kamenná plocha bola zistená v bezprostrednom okolí odkrytej tehlovej cisterny. Interpretácia tejto terénnej situácie je nasledovná. Spevnená plocha vyložená jednoduchým kamenným obkladom bola zhotovená $\mathrm{z}$ toho dôvodu, aby dažd’ová voda nevsakovala do pieskovcového podložia, ale samospádom stekala do vybudovanej cisterny.

Nejednoznačne zodpovedaná ostáva otázka vzniku cisterny. Materiál, z ktorého bola cisterna zhotovená - gotické prstovky - nám ju umožňujú chronologicky zaradit' do obdobia 14.-15. storočia. Hnutel'né archeologické nálezy získané z archeologického výskumu nám dovol'ujú položit' vznik cisterny najskôr do obdobia 15 . storočia.

Zo sondy S 5/2013 bol získaný prevažne keramický materiál vo fragmentárnom stave. $\mathrm{V}$ úrovni $0,60-1,0 \mathrm{~m}$ od pôvodnej úrovne terénu bolo zistené torzo hrnca súdkovitej profilácie $\mathrm{s}$ jemne von roztvoreným a dohora vytiahnutým ústím. Torzo je zdobené rytými obežnými ryhami (tab. I:2). Ako analogický nález k tomuto nálezu môžeme uviest' nález hrnca s identickou profiláciou tela aj ústia z mesta Fil’akovo, z objektu studne objavenej za hradbami pôvodného mestského opevnenia (Hoššo 1985, 235, obr. 2:5). Hrniec je datovaný do 13. storočia až prvej polovice 14. storočia. (Hoššo 1985, 250-251).

Hrniec takmer identickej profilácie tela aj ústia pochádza aj z hradného paláca budínského hradu a je datovaný do 13. storočia (Holl 1963, 368, obr. 66:5). Vyššie opisovaný fragment zarad'ujeme na základe analogických nálezov do 13. storočia. Tento fragment hrnca predstavuje jediný archeologický nález, ktorý môžeme zaradit' do 13. storočia.

Za nález s chronologickou funkciou môžeme označit' aj fragment z hrncovitej nádoby (tab. II:8). Fragment je nevýrazne von roztvorený, ústie je dohora vytiahnuté, hrana ústia je vodorovne zrezaná a je zdobená plastickým pretláčaním. Ako analógiu s takmer identickou profiláciou ústia môžeme uviest' nález hrnca z Rimavskej Soboty (Hoššo 1985, 237, obr. 4:1). Predmetný nález je zaradený do obdobia 16. storočia (Hoššo 1985, 250).

Sondy S 6-7/2013 boli situované vo východnej až juhovýchodnej časti hradného jadra. V sondách v úrovni $0,82-1,05 \mathrm{~m}$ od úrovne pôvodného terénu boli odkryté pozostatky jednopriestorového objektu. Objekt mal obdížnikovitý pôdorys s rozmermi $1,94 \times 3,3 \mathrm{~m}$. Vnútorná svetlost' objektu bola $1,5 \times 2,5 \mathrm{~m}$. Śírka obvodových múrov bola variabilná (južný obvodový múr $0,39-0,40 \mathrm{~m}$, severný obvodový múr $0,65-0,70 \mathrm{~m}$ ). Západná stena objektu bola priamo napojená na kolmo zasekané pieskovcové podložie (obr. 8). Základové lôžko bolo uložené priamo na úroveň pieskovcového podložia, nebolo doň zasekané (zahĺbené). V interiéri objektu bola miestami zistená vrstva vápennej malty s mocnostou $1-2 \mathrm{~cm}$. Vrstvu môžeme interpretovat' ako výmaz 


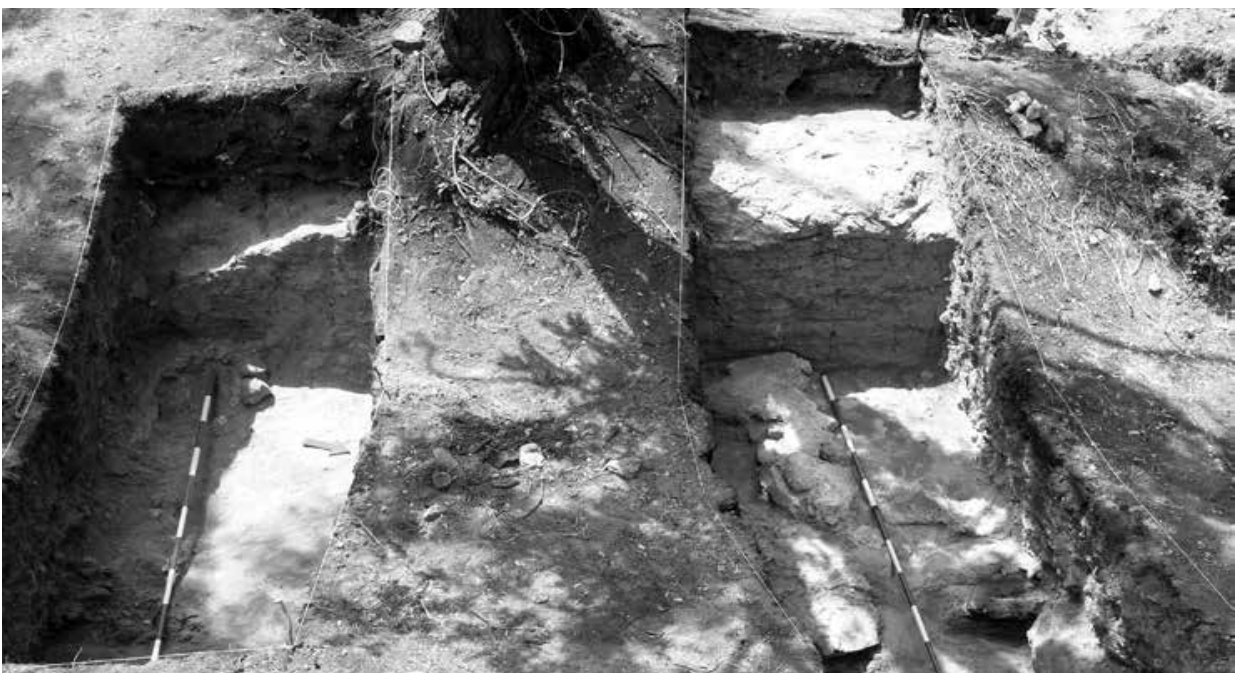

Obr. 8. Hrad Širkovce-Kapla. Základy jednopriestorového objektu odkrytého v sondách S 6-7/2013, 15.-16. storočie. Foto A. Botoš. Abb. 8. Burg Širkovce-Kapla. Fundamente des in den Sondierschnitten S 6-7/2013 freigelegten einräumigen Objektes, 15.-16. Jhdt. Foto A. Botoš.

podlahy. Exteriér objektu podl'ahol požiaru, nakol'ko pieskovcové podložie v okolí odkrytých múrov bolo prepálené dočervena.

Nález torzálnej architektúry interpretujeme ako pozostatok jednopriestorového objektu, pravdepodobne hospodárskej funkcie. Na základe hnutel’ných archeologických nálezov predpokladáme, že jednopriestorový objekt pochádza z obdobia záveru 15. až 16. storočia.

Vo výplni oboch sond bol získaný pomerne bohatý nálezový fond. V sondách boli objavené aj numizmatické nálezy. V sonde $\mathrm{S} 6 / 2013$, v sektore B, v úrovni $0,44 \mathrm{~m}$ od pôvodnej úrovne terénu, bol zistený nález strieborného denáru Ladislava V. Pohrobka z rokov 1453-1457. Druhý nález mince bol zistený i v sonde $\mathrm{S} 6 / 2013$, v sektore A, na úrovni $0,30 \mathrm{~m}$ od pôvodnej úrovne terénu. Mincu sme identifikovali ako denár Rudolfa II. z roku 1580. Obe mince pochádzajú z premiešaných sut'ových vrstiev.

Vo výplni sondy $\mathrm{S} 6 / 2007, \mathrm{v}$ sektore $\mathrm{B}$, v úrovni $0,80 \mathrm{~m}$ od pôvodnej úrovne terénu, sme získali vo fragmentoch, ktoré boli neskôr rekonštruované nález torza komorovej kachli-

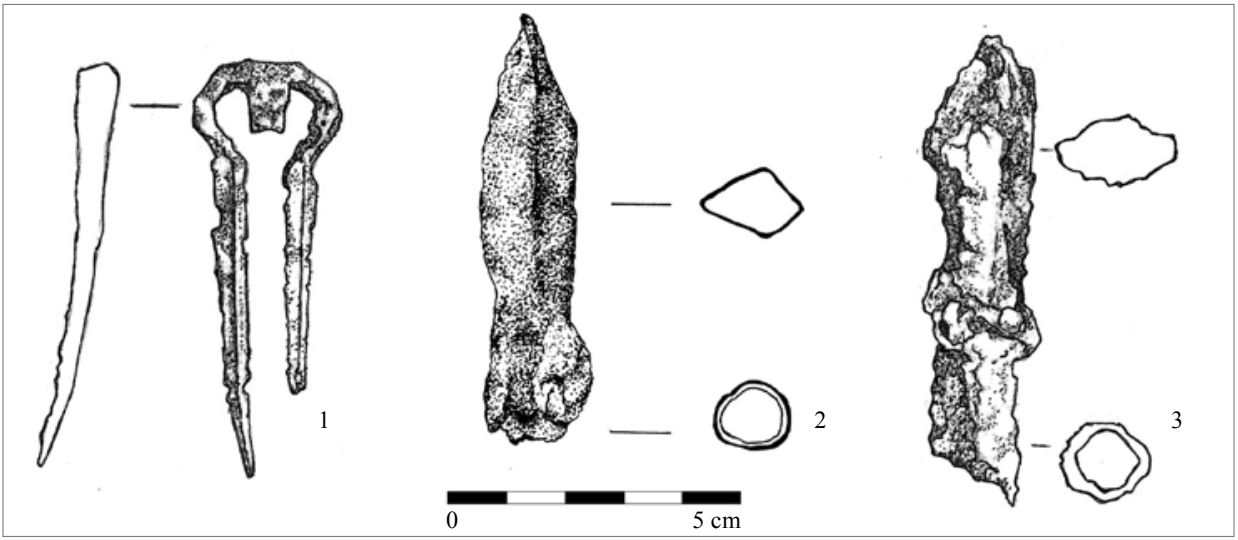

Tab. III. Hrad Širkovce-Kapla. Kovové nálezy. 1 - sonda $S$ 2/2013; 2 - sonda $S$ 3/2013; 3 - sonda $S$ 7/2013. Kresba D. Bešina, L. Podhorčík.

Taf. III. Burg Širkovce-Kapla. Metallfunde. 1 - Sondierschnitt S 2/2013; 2 - Sondierschnitt S 3/2013; 3 - Sondierschnitt S 7/2013. Zeichnung D. Bešina, L. Podhorčík. 
ce. Zachovaná je len čelná vyhrievacia stena kachlice s rozmermi $25,3 \times 23,6 \mathrm{~cm}$, s vyobrazením šest'lupienkovej rozety. Kachlica je opatrená polychrómnou glazúrou žltozelenej farby (tab. IV:1).

V blízkych Rimavských Janovciach bolo počas archeologického výskumu bývalého benediktínskeho kláštora zistené torzo komorovej kachlice s vyobrazením rozety podobného znázornenia (Hrašková-Kürthy-Ragač-Šimkovic 2001, 282, obr. 2:2). Nález kachlice je autormi výskumu zaradený do druhej polovice 15. storočia (Hrašková-Kürthy-Ragač-Šimkovic 2001, 292).

Ako d'alší analogický nález s takmer identicky formovanou sedemlupienkovou rozetou môžeme uviest' nález komorovej kachlice z Banskej Štiavnice, z Komorského dvora (Labuda 2005, 181, obr. 11). J. Labuda $(2005,181)$ predmetnú kachlicu zaradil do 15 . storočia.

Nález fragmentu kachlice s vyobrazením podobnej rozety ako z hradu Kapla pochádza aj z Banskej Bystrice - Dolnej ulice (Mácelová 2009, 409, obr. 13:1-2). Nález tejto kachlice

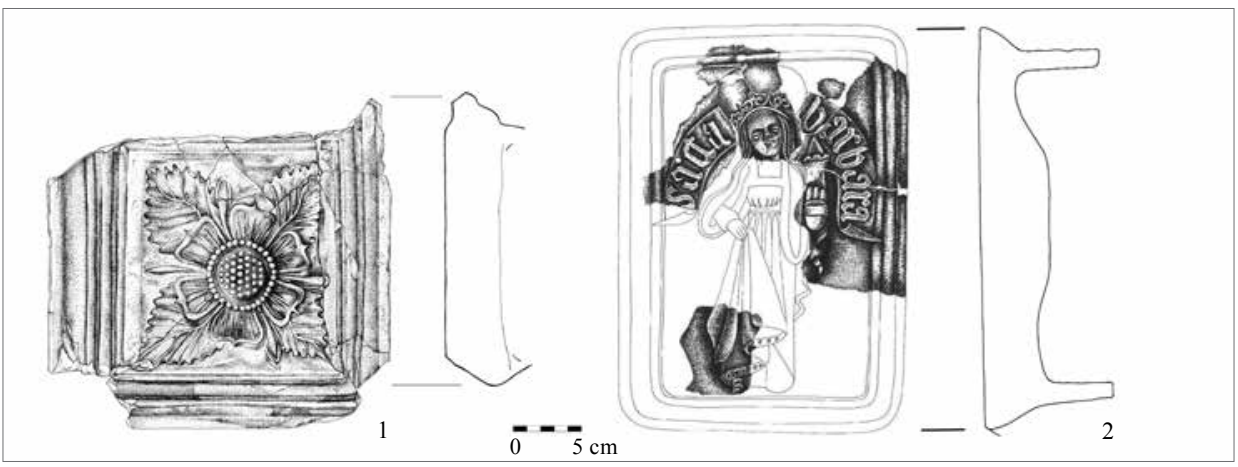

Tab. IV. Hrad Širkovce-Kapla. Nálezy kachlíc. 1 - torzo komorovej kachlice s vyobrazením šest'lupienkovej rozety, 16. storočie; 2 - torzo komorovej kachlice s vyobrazením sv. Barbory, 16. storočie. Kresba D. Bešina, A. Nagyová.

Taf. IV. Burg Širkovce-Kapla. Kachelfunde. 1 - Torso einer Blattkachel mit sechsblättriger Rosette, 16. Jhdt.; 2 - Torso einer Blattkachel mit Hl. Barbara, 16. Jhdt. Zeichnung D. Bešina, A. Nagyová.

patrí do okruhu banskobystrickej kachliarskej dielne a je chronologicky zaradený do poslednej štvrtiny 15. storočia (Mácelová 2009, 412).

Ďalší nález takmer identicky formovanej rozety ako hodnotený nález pochádza rovnako z Banskej Bystrice - Dolnej ulice, z pozostalosti Dr. Samuela Bothára, ktorý kachlice zo svojho pozemku ponúkol Umelecko-priemyselnému múzeu v Budapešti (Cserey 1974, 209, obr. 4).

Na základe vyššie uvedených analógií kachlicu zarad'ujeme s ohl'adom na aplikáciu polychrómnej glazúry do obdobia 16 . storočia.

Zo sond S 6-7/2013, z úrovne $0,50-0,80 \mathrm{~m}$ od pôvodnej úrovne terénu, boli zistené fragmenty komorových kachlíc s vyobrazením ženskej postavy v honosných šatách. Postava v l'avej ruke drží vežu s okrúhlym pôdorysom, špicatou strieškou, tromi oknami a jednými vstupnými dverami. Hlava postavy je zobrazená s královskou korunou s dlhými vlnitými vlasmi, ktoré siahajú po plecia postavy. Okolo postavy je zachovaná nápisová páska v gotickej minuskule v tvare „Sacta Barbara“. Kachlica je opatrená polychrómnou glazúrou žltozelenej farby, čelná vyhrievacia plocha kachlice je obdížnikovitá, s rozmermi 20,5×30,5 cm (tab. IV:2).

Na základe kruhopisnej pásky, ako aj atribútu svätice - veže, interpretujeme ženskú postavu ako sv. Barboru. Sv. Barbora bola patrónkou baníkov, strelcov, stavitel’ov, tesárov.

Komorová kachlica s ikonografiou sv. Barbory pochádza napr. z Banskej Bystrice - Dolnej ulice (Mácelová 2009, 407, obr. 8:2-3). Tieto fragmenty sú zaradené do poslednej tretiny 15. storočia a patria do okruhu banskobystrickej kachliarskej dielne (Mácelová 2009, 412).

Nález fragmentu keramickej formy s vyobrazením sv. Barbory pochádza zo zaniknutého kláštora v Slovenskej L’upči (Hanuliak 2001, 6).

Nález torza kachlice s ikonografiou sv. Barbory pochádza aj z hradu Parič v Trebišove (Chovanec 2005, 50, obr. 26). Kachlica je chronologicky zaradená do obdobia okolo roku 1504 (Chovanec 2005, 39). 
Posledný známy nález komorovej kachlice z územia Slovenska s ikonografiou sv. Barbory pochádza z hradu Šintava a je datovaný do 16. storočia (Kvietok-Mácelová 2013, 53).

Rekonštruovanú kachlicu s ikonografiou sv. Barbory z hradu Kapla zarad'ujeme s ohl'adom na aplikáciu polychrómnej glazúry do obdobia 16. storočia.

Zo sondy $\mathrm{S} 7 / 2013$, z úrovne $0,70-0,80 \mathrm{~m}$ od pôvodnej úrovne terénu, boli zistené fragmenty komorovej rímsovej riadkovej kachlice s cimburím. Kachlica je v horizontálnom smere rozdelená na tri polia. Na najvrchnejšom poli je situovaná čast' nápisu v gotickej minuskule $\mathrm{v}$ tvare „MA“. Celý nápis rekonštruujeme v tvare „MARYA“. Na cimburiach kachlice je zobrazený motív ludskej tváre (?). V strednom poli je situovaný motív architektúry - stípa, okolo ktorého sú ob-

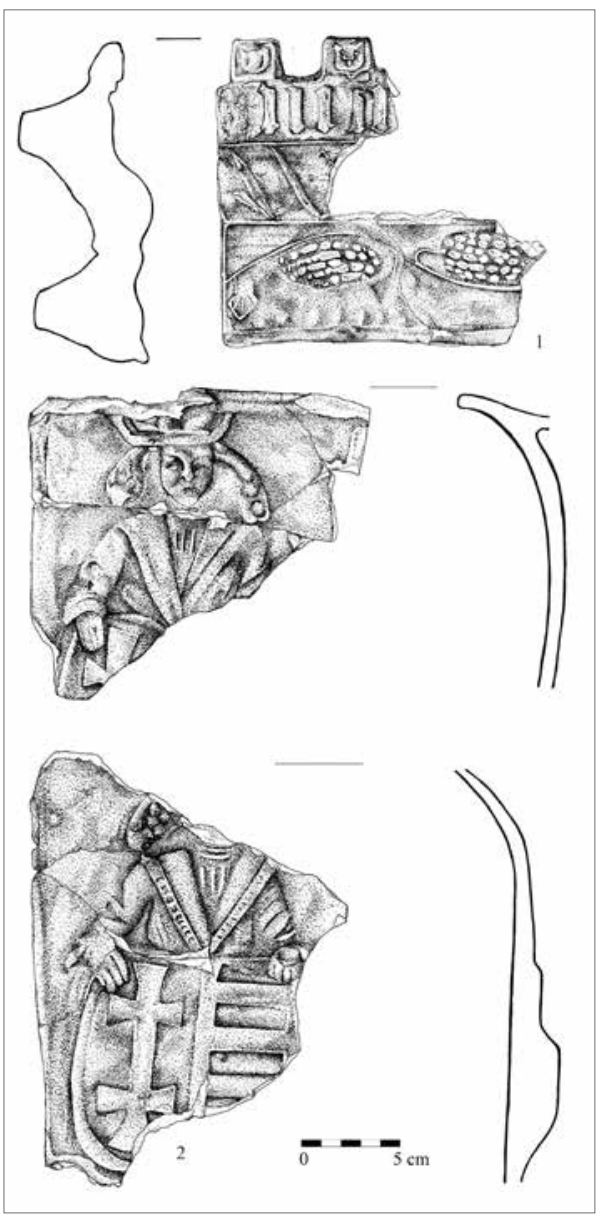

Tab. V. Hrad Širkovce-Kapla. Nálezy kachlíc. 1 - torzo rímsovej riadkovej kachlice s cimburím a s nápisom v gotickej minuskule „MA“, prelom 15.-16. storočia; 2 - torzá rímsových kachlíc s vyobrazením herolda v rukách držiaceho uhorský erb, prelom 15.-16. storočia. Kresba D. Bešina.

Taf. V. Burg Širkovce-Kapla. Kachelfunde. 1 - Torso einer mit Zinnen versehenen Gesimskachel mit gotischer Minuskelinschrift MA, Wende 15.-16. Jhdt.; 2 - Torso einer Gesimskachel mit Herold, das ungarische Wappen haltend, Wende 15.-16. Jhdt. Zeichnung D. Bešina. točené plastické lišty. V dolnom poli je situovaný rastlinný motív $\mathrm{v}$ podobe dvoch strapcov hrozna, ako aj listu viniča. Fragmenty sú opatrené polychrómnou glazúrou žltozelenej farby (tab. V:1).

Úplne identická kachlica ako vyššie opísaná kachlica z hradu Kapla pochádza z lokality Rimavská Sobota - Kurinec-Barát kút (Mníchova studňa). Kachlica je rovnako opatrená cimburím a nápisom $v$ gotickej minuskule „MARYA“. Kachlica je chronologicky zaradená do posledných desat'ročí 15 . storočia (Botoš 2012, 14).

V regióne Gemera-Malohontu je doložený aj d’alší nález rímsovej kachlice s cimburím a nápisom v gotickej minuskule „MARYA“, objavený počas archeologického výskumu bývalého benediktínskeho kláštora $\mathrm{v}$ Rimavských Janovciach (Hrašková-Kürthy-RagačŠimkovic 2001, 282, obr. 2:2). Nález kachlice je autormi výskumu zaradený do druhej polovice 15. storočia (Hrašková-Kürthy-RagačŠimkovic 2001, 292).

Ako blízky analogický nález $\mathrm{k}$ tomuto nálezu kachlice môžeme uviest' nález rímsovej kachlice z Kežmarského hradu, ktorá je rovnako opatrená nápisom v minuskule „MARYA“, z 15. storočia (Holčík 1978, obr. 56).

Takmer úplne identická rímsová kachlica pochádza aj z novohradského mesta Sečany - ul. E. Adyho, kde pri výstavbe kultúrneho domu bola objavená rímsová kachlica s cimburím. Čelná vyhrievacia stena kachlice je identicky rozdelená na tri vertikálne polia. V najvrchnejšom poli je situovaný nápis v gotickej minuskule „MARIA PANNO“, v strednom poli je situovaný motív stípa, okolo ktorého sú obtočené plastické lišty. V dolnom poli sečianskej kachlice je rovnako situovaný rastlinný motív v podobe dvoch strapcov hrozna a listov viniča (Bodnár 1988, tab. VII: 11).

K. Bodnárová predpokladá, že kompletné znenie nápisu je „MARIA PANNONIAE REGINA“ (Bodnár 1988, 12). Autorka štúdie zaradila kachlicu do 15. storočia (Bodnár 1988, 21). 


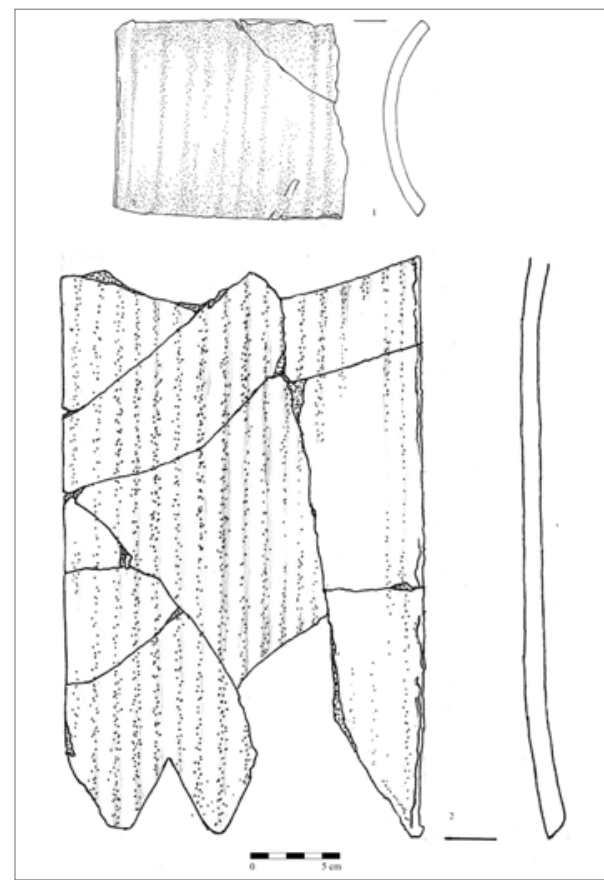

Tab. VI. Hrad Širkovce-Kapla. Technická keramika. 1 - torzo korýtka, 15.-16. storočie; 2 - škridlica ukončená vruborezom, 15.-16. storočie. Kresba L. Podhorčík.

Taf. VI. Burg Širkovce-Kapla. Technische Keramik. 1 - Torso einer Rinne, 15.-16. Jhdt.; 2 - gezahnte Dachziegel, 15.-16. Jhdt. Zeichnung L. Podhorčík.

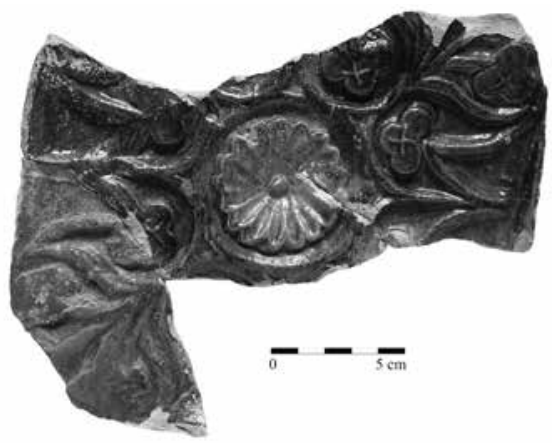

Obr. 9. Hrad Širkovce-Kapla. Torzo komorovej kachlice s vyobrazením rozety a florálného motívu, 2 . polovica 16.-17. storočia. Foto J. Ferlet'áková.

Abb. 9. Burg Širkovce-Kapla. Torso einer Blattkachel mit Rosette und floralem Motiv, 2. Hälfte 16.-17. Jhdt. Foto J. Ferlet’áková.
Ako d’alší analogický nález k predmetnej kachlici môžeme uviest' nález rímsovej kachlice s cimburím s nápisom $\mathrm{v}$ gotickej minuskule „MARYA“ z Mestského hradu v Banskej Bystrici. Nález banskobystrickej kachlice je zaradený do prelomu 15.-16. storočia (Kvietok-Mácelová 2013, 26).

Na základe vyššie uvedených analogických nálezov predpokladáme, že fragmenty rímsovej kachlice so zachovaným nápisom „MA“ môžeme zaradit' do obdobia prelomu 15. a 16. storočia.

Zo sondy $\mathrm{S} 7 / 2013$, z úrovne $0,50-0,90 \mathrm{~m}$ od pôvodnej úrovne terénu, boli zistené aj fragmenty komorových kachlíc, na ktorých je zobrazená postava štítonosiča (herolda) $\mathrm{s}$ dlhými kučeravými vlasmi, ktorý $\mathrm{v}$ rukách drží uhorský erb (tab. V:2).

Postava anjela $\mathrm{v}$ podobe štítonosiča sa začala uplatňovat' $\mathrm{v}$ heraldických zobrazeniach od druhej polovice 14. storočia, pričom svoju oblubu si udržiaval ešte aj v 15 . storočí. Hojne sa vyskytoval v král'ovských, cirkevných či mestských erboch. Samotná figúra anjela je vnímaná ako symbol posla dobrých správ.

Ako úplne identické analogické nálezy k vyššie opísanej kachlici môžeme uviest' nálezy kachlíc so štítonosičom z hradu Fil'akovo (Kalmár 1959, tab. LXIV). J. Kalmár ich chronologicky zaradil do obdobia prelomu 15. a 16. storočia (Kalmár 1959, 31).

Š. Holčík zaradil rímsové kachlice so štítonosičom z Filakovského hradu do obdobia konca 15. storočia (Holčík 1978, obr. VIII.-IX.).

Ďalšie úplne identické analogické nálezy komorových kachlíc s vyobrazením štítonosiča boli objavené na pozemku Dr. Samuela Bothára na Dolnej ulici č. 35 v Banskej Bystrici a sú zaradené do konca 15. storočia (Cserey 1978, 206, obr. 1). Kachlice s identickým motívom pochádzajú aj z Komorského dvora z Banskej Štiavnice, ktoré sú rovnako datované do 15. storočia (Labuda 2005, 180, obr. 1).

Na základe vyššie uvedených analógií predpokladáme, že fragmenty kachlíc s vyobrazením štítonosiča z hradu Kapla pochádzajú z obdobia prelomu 15. a 16. storočia.

V sonde S 7/2013, v úrovni $0,50-0,90 \mathrm{~m}$ od pôvodnej úrovne terénu, bolo zistené torzo komorovej kachlice, na ktorej je zobrazený plastický florálny motív v kombinácii s rozetami. Fragmenty sú opatrené polychrómnou glazúrou zelenožltej farby (obr. 9). Kachlice s podobnou textúrou pochádzajú z hradov Ónod a Szendrő (Tomka 2005, 238, 240) a sú zaradené do obdobia druhej polovice 16. storočia až začiatku 17. storočia. 
Torzo kachlice na základe analogických nálezov zarad’ujeme do obdobia druhej polovice 16. storočia až 17. storočia.

V sondách boli zistené aj torzá nádobkových a hrncovitých kachlíc. Pomerne unikátne sú nálezy stavebnej keramiky - strešnej krytiny (torzo škridlice a torzo korýtka). Na základe sprievodných nálezov ich zarad'ujeme do obdobia 15.-16. storočia (tab. VI:1-2).

V sonde S 7/2013, v híbke $0,48 \mathrm{~m}$ od pôvodnej úrovne terénu, bol zistený nález železného hrotu (strelky) romboidnej profilácie (tab. III:3). Strelku môžeme na základe ostatných nálezov zaradit' do obdobia 15.-16. storočia.

Všetky sondy otvorené vo výskumnej sezóne 2013 boli situované vo východnej časti hradného jadra, v jeho najexponovanejšej časti, kde sme predpokladali aj doloženie najstaršej stavebnej fázy hradu z 13. storočia. Žial', túto stavebnú etapu sme nepreukázali, počas archeologického výskumu sme zistili len jediný nález (torzo hrnca), ktorý môžeme zaradit' do 13. storočia. Predpokladáme, že najstaršia stavebná etapa hradu bude s najväčšou pravdepodobnost'ou situovaná v centrálnej časti hradného jadra. Túto hypotézu môže potvrdit' len d’alší archeologický výskum.

\section{Literatúra}

BODNÁR, K., 1988: Kályhacsempék Nógrád megyéből I. Szécsény mezőváros XV.-XVI. századi kályhacsempeí - Ofenkacheln aus dem Komitat Nógrad I. Die Ofenkacheln des Marktfleckens Szécsény aus den XV-XVIten Jahrhunderten, Nógrád megyei múzeumok évkönyve 14, 9-24.

BOTOŠ, A., 2012: Rymoa Zumbota. Rimavská Sobota v stredoveku a v novoveku. Katalóg k výstave. Rimavská Sobota.

CSEREY, S. E., 1974: Adatok a beszterczebányai (Banská Bystrica) kályhacsempékhez - Zu den Offenkacheln von Besztercebánya (Banská Bystrica), Folia archeologica 25, 205-217.

HANULIAK, V., 2001: Zaniknutý stredoveký kláštor v Slovenskej L’upči, Pamiatky a múzeá, č. 2, 2-8.

HOLČÍK, Š., 1978: Stredoveké kachliarstvo. Bratislava.

HOLL, I., 1963: Középkori cserépedények a budai várpalotábol (XIII.-XV. század) - Mittelalterliche Keramik aus dem Burgpalast von Buda (13.-15. Jahrhundert), Budapest régiségei 20, 335-394.

HOŠŠO, J., 1985: Stredoveké hrnčiarstvo na území Gemera, Novohradu a Hontu. In: Vlastivedné štúdie Gemera 3 (Bolfík, J., ed.), 230-262. Rimavská Sobota.

HRAŠKOVÁ, E.-KÜRTHY, L.-RAGAČ, R.-ŠIKOVIC, M., 2001: Pamiatkový prieskum a zistovací archeologický výskum kostola a zaniknutého benediktínskeho kláštora v Rimavských Janoviciach - Denkmal und archäologische Erforschung der Kirche und des untergegangenen Benediktinerklosters in Rimavské Janovce, AH 26, 279-298.

CHOVANEC, J., 2005: Palatínska kachlová pec Imricha Perényiho - Der Palatinerofen Imich Perényi. In: Gotické a renesančné kachlice v Karpatoch - Gotische und renaissance-Kacheln in den Karpaten (Chovanec, J., ed.), 23-54. Trebišov.

KALMÁR, J., 1959: A füleki (Filakovo) vár XV.-XVII. századi emlékei - Die Denkmäler der Burg Filakovo aus dem XV-XVII. Jahr. Budapest.

KOL., 1969: Súpis pamiatok na Slovensku. Zväzok III. R-Ž. Bratislava.

KOL., 1978: Vlastivedný slovník obcí na Slovensku. Zväzok III. Bratislava.

KVIETOK, M.-MÁCELOVÁ, M., 2013: Krása kachlíc. Vzácne neskorogotické a renesančné kachlice. Katalóg výstavy. Banská Bystrica.

LABUDA, J., 2005: Zaujímavé kachlice z Banskej Štiavnice a Sitna - Interessante Kacheln von Banská Štiavnica (Schemnitz) und die Burg Sitno. In: Gotické a renesančné kachlice v Karpatoch - Gotische und renaissance-Kacheln in den Karpaten (Chovanec, J., ed.), 175-182. Trebišov.

LÁZÁR, S., 1986: Az Egri vár törökkori magyar cserépedényi, Agria 22, 35-63.

MÁCELOVÁ, M., 2009: Nepublikovaný súbor neskorogotických kachlíc z Dolnej ulice v Banskej Bystrici - Ein nicht veröffentlicher Komplex spätgotischer Kacheln aus der Dolná-Str. in Banská Bystrica, AH 34, $399-413$.

NEKUDA, V.-REICHERTOVÁ, K., 1968: Středověká keramika v Čechách a na Moravě. Brno.

PLAČEK, M.-BÓNA, M., 2007: Encyklopédia slovenských hradov. Bratislava.

POLIAK, M., 2012: Fenomén dažd’ovej vody na hradoch - Phenomenon of rainfall water in the castles, Monumentorum Tutela 24, 57-76.

RUSNÁK, R., 2009: Novšie nálezy stredovekých kovových predmetov z Košíc - Die neuesten Funde mittelalterlicher Metallgegenstände aus Košice, AH 34, 393-407.

TOMKA, G., 2005: Zwei Ofenkachelgruppen von den Burgen Ónod und Szendrő - Dve skupiny kachlíc z hradov Ónod a Szendrő. In: Gotické a renesančné kachlice v Karpatoch - Gotische und renaissance-Kacheln in den Karpaten (Chovanec, J., ed.), 231-240. Trebišov. 


\section{Zusammenfassung}

\section{Die archäologische Grabung auf der wüsten Burg Širkovce-Kapla (Bezirk Rimavská Sobota)}

Die wüste Burg Kapla liegt auf einem dominanten Hügel im südwestlichen Teil des AuBenbereichs der Gemeinde Širkovce. Auf der Burg wurde bisher keine archäologische Grabung durchgeführt. Von Feldbegehungen ist eine Besiedelung des Burghügels im Äneolithikum, in der späten Bronzezeit, in der Latènezeit sowie in der jüngeren Römerzeit bekannt.

Die im 13. Jahrhundert errichtete Burg war ursprünglich der Familiensitz des Adelsgeschlechts Ratold und ging im 16.-17. Jahrhundert während den Türkenkriegen unter.

Die genaue Objektzusammensetzung der Burg ist gegenwärtig insofern unbekannt, als dass auf der Burg keine oberirdischen Bauten erhalten geblieben sind. Die Ausdehnung der Kernburg ist verhältnismäßig klein, das Kernareal ist rechteckförmig und hat die Maße von ca. $55 \times 20 \mathrm{~m}$.

Während der archäologischen Grabung in der Saison 2013 wurden insgesamt sieben Sondierschnitte gelegt, die als S 1-7/2013 kenntlich gemacht wurden. Die Sondierschnitte befinden sich an zwei markanten Geländesenken im östlichen Teil der Kernburg.

Mit den Sondierschnitten S 1-5/2013 wurden die aus gebrannten Ziegelsteinen bestehenden Grundmauern der Burgzisterne mit den Ausmessungen von 2,02 $\times 3,45 \mathrm{~m}$ freigelegt. Die Zisterne stammt aus der Zeit des 15. Jahrhunderts. Im Innern der Zisterne entdeckte man in einer Tiefe von 3,98 m unter dem ursprünglichen Geländeniveau einen Fußboden aus gebrannten Fliesen. Die Höhe der aus gebrannten Ziegelsteinen bestehenden Mauer betrug vom Fußboden bis zur erhaltenen Mauerkrone 2,93-2,96 m. Die Wände der Zisterne waren mit einem feinkörnigem Kalkputz vergipst, der eine Stärke von bis zu $2 \mathrm{~cm}$ aufwies.

In den Sondierschnitten S 1/2013, S 4/2013 und S 5/2013 wurde in unmittelbarer Umgebung der freigelegten Zisterne eine mit Steinen befestigte Fläche freigelegt (im Trockenbett ausgelegte flache Steine). Der Sandsteinuntergrund war terrassenartig zugehauen. Diese Herrichtung erfolgte aus dem Grund, damit kein Regenwasser in den Sandsteinuntergrund hineinsickert, sondern durch Eigengefälle in die angelegte Zisterne abfließt.

In den Sondierschnitten S 6-7/2013 wurden die Fundamente eines einräumigen Wirtschaftobjektes mit den Abmessungen 1,94 $\times 3,3 \mathrm{~m}$ freigelegt, das in den Zeitraum Ende 15. bis 16. Jahrhundert datiert wurde. Die Westwand des Objektes schloss direkt an den senkrecht zugehauenen Sandsteinuntergrund an. Im Innern des Objektes wurde stellenweise eine Schicht Kalkmörtel (Fußbodenestrich) mit einer Stärke von 1-2 cm entdeckt. Außen war das Objekt von einem Brand erfasst worden, weswegen der Sandsteinuntergrund in der Umgebung der freigelegten Mauern eine rötliche Färbung angenommen hat.

In den Sondierschnitten wurden Fragmente von Blattkacheln entdeckt, deren Motive die Hl. Barbara, Rosetten und einen Herold zeigten, bzw. in einem Fall die Aufschrift „MA“ aufwies, die von uns als „MARYA“ interpretiert wurde.

Die Sondierschnitte S 1-7/2013 wurden im östlichen Teil der Kernburg gelegt, und zwar in dessen exponiertestem Teil, wo wir Belege für die älteste Bauphase der Burg aus dem 13. Jahrhundert vermuteten. Leider konnten wir diese Bauetappe nicht nachweisen, während der archäologischen Grabung haben wir lediglich einen einzigen Fund (den Torso eines Topfes) gemacht, den wir dem 13. Jahrhundert zuordnen können. Wir vermuten, dass die älteste Bauetappe der Burg höchstwahrscheinlich im zentralen Teil der Kernburg liegt. Diese Hypothese kann nur durch eine weitere archäologische Grabung bestätigt werden.

PhDr. Alexander Botoš, Gemersko-malohontské múzeum, Nám. M. Tompu č. 5, SK 97901 Rimavská Sobota,botos@gmmuzem.sk 
